NBER WORKING PAPER SERIES

ON

HISTORICAL FACTORS IN LONG RUN GROWTH

SOUTH CAROLINA SLAVE PRICES, 1722-1809

\author{
Peter C. Mancall \\ Joshua L. Rosenbloom \\ Thomas Weiss
}

Historical Paper 123

\author{
NATIONAL BUREAU OF ECONOMIC RESEARCH \\ 1050 Massachusetts Avenue \\ Cambridge, MA 02138 \\ March 2000
}

We thank Joyce Chaplin for providing a machine-readable copy of her sample of South Carolina and Georgia probate inventories. We are also indebted to Peter Coclanis, Stanley Engerman, Farley Grubb, Ted Juhl, Shigeru Iwata, and Jonathan Pritchett for their comments on an earlier version of this paper. This research is funded in part by the National Science Foundation (SBR9808516) and the General Research Fund of the University of Kansas. Any opinions expressed are those of the authors and not those of the National Bureau of Economic Research.

(C) 2000 by Peter C. Mancall, Joshua L. Rosenbloom and Thomas Weiss. All rights reserved. Short sections of text, not to exceed two paragraphs, may be quoted without explicit permission provided that full credit, including $(\mathcal{C}$ notice, is given to the source. 
South Carolina Slave Prices, 1722-1809

Peter C. Mancall, Joshua L. Rosenbloom, and Thomas Weiss

NBER Historical Paper No. 123

March 2000

Development of the American Economy

\begin{abstract}
Based on data from several samples of probate inventories we construct and analyze a time series of slave prices for South Carolina from 1722 to 1809 . These estimates reveal that prices fluctuated without trend prior to the 1760 s and then began to rise rapidly, more than doubling by the early nineteenth century. Estimates of supply and demand functions indicate that while long-run slave supply was highly elastic, the short-run supply function was quite inelastic. Our analysis of the slave price series indicates that the price of rice was the major determinant of the demand for slaves and in turn largely explains the rise in slave prices. These findings have important implications for the interpretation of evidence on rising yields in rice production over the eighteenth century and the sources of wealth accumulation in South Carolina.
\end{abstract}

Peter C. Mancall

Department of History

University of Kansas

Lawrence, KS 66045

Pmancall@ukans.edu
Joshua L. Rosenbloom

Department of Economics

University of Kansas

Lawrence, KS 66045

and NBER

Jrosenbloom@ukans.edu
Thomas Weiss

Department of Economics

University of Kansas

Lawrence, KS 66045

and NBER

Tweiss@falcon.cc.ukans.edu 


\section{South Carolina Slave Prices, 1722-1809}

Slavery was central to the economic development of South Carolina in the eighteenth century. Slaves were a majority of the population and labor force for much of the century, and made up close to half of the personal wealth recorded in probate inventories in most decades. Despite the proliferation of studies examining various facets of the slave-based economy of South Carolina in recent years, there has been no serious consideration of the evolution of slave prices in the course of the eighteenth century. ${ }^{1}$ As the most important productive asset of the economy, and a key component of the region's wealth, however, information on slave prices is a crucial indicator that can shed new light on the pace and pattern of economic growth in the lower South. The data necessary to construct a series of slave prices are available in samples of probate inventories from the region collected by several scholars for the entire period from the early 1720 s through the first decade of the nineteenth century, but have not previously been examined.

Using data drawn from probate inventories between 1722 and 1809 we present and analyze a new series of prices for adult male slaves in low country South Carolina. Our slave price series shows fluctuations but no trend before 1770, and a sharp rise thereafter. This increase was interrupted briefly in the 1790 s, but by the first decade of the nineteenth century prices had more than doubled from their mid-eighteenth century levels. This history can readily be interpreted in terms of movements in the supply of and demand for slaves in South Carolina. Based on an econometric model of the market for slaves we conclude that although shifting

\footnotetext{
${ }^{1}$ Among the most important general economic histories are those by Philip Morgan (1998), Joyce Chaplin (1993), and Peter Coclanis (1989). Other important contributions include Menard (1995, 1988), Bentley (1977), Terry (1981), Nash (1992), Egnal (1998, ch. 6), Ryden (1993), Richardson (1991).
} 
supply conditions played some role in determining slave prices, demand-side forces, and especially movements in the price of rice - the principal export crop produced using slave labor in South Carolina - explain most of the movements in slave prices.

The evolution of slave prices that we document bears directly on two important issues in the economic history of South Carolina. The first concerns the effects of shifting cultivation practices on agricultural productivity. Scholars have argued that the development of new methods of irrigation during the eighteenth century contributed to a substantial increase in the productivity of rice growing. ${ }^{2}$ But the behavior of slave prices is inconsistent with such an interpretation. Though we cannot rule out some improvement in productivity, it appears that progress was more modest than has previously been believed. The second issue concerns the sources of wealth accumulation in the lower south. On the eve of the Revolution, the per capita wealth of South Carolina's free population exceeded that of any other region of what would become the United States. Our estimates show that rising slave prices can account for much of the dramatic increase in the region's wealth levels in the decades prior to the 1770 s. This does not, of course, alter estimates of relative regional wealth, but it does place such estimates in a rather different light. Instead of reflecting the continued accumulation of real assets by the colony's inhabitants, increased wealth was due largely to rising asset prices especially the rising price of slaves.

\section{An Overview of South Carolina's Economic Development}

Staple agricultural production dominates the economic history of South Carolina in the eighteenth and early nineteenth centuries. Rice was the most important crop, though after 1740

\footnotetext{
${ }^{2}$ See, for example, Coclanis (1989, p. 96). As we note below, his interpretation has been widely accepted by other scholars.
} 
indigo exports grew dramatically and at the end of the century cotton emerged as an important crop. ${ }^{3}$ Roughly speaking we may divide the period into three distinct episodes. The first, running from the beginning of the century to the mid-1770s was characterized by the sustained expansion of rice cultivation. The second episode, from the beginning of the Revolution through the early 1790s, was one of transition. During these years production of the state's leading staples was essentially stagnant, and the center of gravity of the economy began to shift toward the interior where population growth was proceeding rapidly. ${ }^{4}$ The third period, dating roughly from the mid-1790s, saw the beginning of a new phase of growth based on the introduction and rapid adoption of cotton cultivation.

In 1700, 31 years after European settlement, South Carolina's population had grown to about 5,700, including 2,444 slaves (see Table 1). ${ }^{5}$ Although there is evidence that the colonists began to grow rice as early as the mid-1690s, it remained a minor crop until after the turn of the century. In the seventeenth century cattle raising, production of naval stores, and deerskins (acquired through trade with the indigenous population) constituted the bulk of the colonial economy. Though colonists benefited from these developments, the first settlers' initial economic success derived from the importation of Africans who had experience tending freeranging cattle (an activity unknown in England). ${ }^{6}$

\footnotetext{
${ }^{3}$ Coclanis (1989) provides the most extensive account of South Carolina's economic history.

${ }^{4}$ Until the cotton boom of the 1790s the backcountry economy was based on largely self-sufficient family farms. On the backcountry economy see Hughes (1985), Johnson (1997), Klein (1990).

${ }^{5}$ In addition to these European and African residents, the region was also home to a large aboriginal population. It is difficult, however, to estimate Indian populations within specific colonial boundaries. For the lower South as a whole_-including Georgia and North Carolina as well as South Carolina_-Indians made up perhaps $80 \%$ of the regional population in 1700. Because Indian populations fell across the eighteenth century, while the numbers of colonists and slaves grew, the Indian share of regional population fell dramatically, so that by 1800 , they represented just $4 \%$ of the total regional population. See Mancall, Rosenbloom, and Weiss (1999, Table 3).

${ }^{6}$ Coclanis (1989, pp. 63-69); Menard (1996, p. 275); Dethloff (1982, p. 233); Clifton (1981, p. 274); Nash (1992, pp. 679-81); Wood (1974, pp. 29-31).
} 
Carolina's rice revolution began after 1700. Driven by rising European demand for rice, exports increased from 450 thousand pounds in 1700 to 6.5 million pounds in 1720 (see Figure 1). Although European demand conditions turned less favorable after 1720, rice prices in South Carolina continued to rise for most of the next two decades, approximately doubling between 1720 and their peak in $1738 .^{7}$ Responding to rising prices the volume of rice exports continued its upward trend, reaching a peak of 43 million pounds in 1740.

As rice production expanded, cultivation shifted from upland areasto more productive inland swamps. Early settlers had relied upon rainfall to provide adequate irrigation. In the early 1720 s colonists recognized that lowland swamps could be used to irrigate their crops so they shifted cultivation to take advantage of nearby ponds and reservoirs. At this point, irrigation was limited to supplying moisture. Not until the widespread adoption of tidal irrigation later in the century would planters begin to use water to systematically control weeds, and insects (Gray 1958, p. 279). Irrigation raised yields, but was also more labor intensive. Construction and maintenance of the dikes, canals, and floodgates necessary to implement this shift required large amounts of labor. Rice cultivation also required a great deal of weeding: difficult and unpleasant work performed ankle- or even knee-deep in mud. According to contemporary estimates successful plantations required a labor force of 30 or more slaves (Chaplin, 1992, pp. 31-33; Philip Morgan 1998, pp. 35-37). To meet these labor demands, slave imports boomed. Between 1700 and 1720, planters imported 9,000 slaves (see Table 2), contributing to a more than 4-fold increase in the slave population. By 1720 the slave share of the population increased to 70 percent, reaching its highest level. In the next twenty years planters purchased more than 32,000

\footnotetext{
${ }^{7}$ On European demand conditions in this period, see Nash (1992, pp. 685-86). That South Carolina prices continued to rise in the face of relatively stagnant European demand may be attributed to economies of scale in shipping, and the beneficial effects of Britain's decision to allow direct shipments of rice from the colonies to ports in Southern Europe, thus reducing the burden previously imposed on rice exports by the requirement that all exports to Europe
} 
additional slaves, nearly 3 times the number of slaves resident in the colony in 1720 . Despite this importation, the slave population increased by just 18,000 over these years. The gap between imports and increases in population reflects the harsh demographic regime. As long as deaths outnumbered births among slaves in the colony slaveholders had to import slaves simply to replace these losses.

The initial period of rice expansion came to a sudden end in 1740. In 1739, the Stono rebellion, in which slaves killed 39 colonists, contributed to the planters' fears about the growing black majority in the colony, and resulted in the passage of a prohibitive duty on slave imports which lasted until 1744 (Richardson 1991, p. 131, Crouse 1977, p. 56, Wood 1974, pp. 308-26). At nearly the same time King George's War (1739-48) substantially raised shipping and insurance costs, restricting the market for rice (Menard 1988, pp. 251-52). As Figure 1 shows, prices plummeted, and exports fell along with them after 1739. Slave imports also fell precipitously (Table 2), dropping to only a fraction of their level in the previous decade. The depressed conditions persisted for most of the 1740s. But the economic downturn did not spell the end of the colonial economy. During this period planters experimented with other crops, including indigo, which emerged as an important complement to rice. British bounties made indigo commercially attractive, and because it was less bulky than rice, it was less affected by the wartime rise in shipping costs. Moreover, since it could be grown on lands not suited to rice cultivation, and its peak labor demands did not coincide with those of rice cultivation, planters could add indigo without substantially reducing their commitment to rice (Gray 1958, p. 289). By 1748 , indigo already accounted for $10.4 \%$ of South Carolina's exports, putting it third in importance behind deerskins, 22\%, and rice, 55\% (Coclanis 1989, p. 80).

pass through Britain (Dethloff 1982, p. 236). 
With the return of peace in the late 1740 s, rice prices recovered along with exports, and the importation of slaves resumed. Then in the early 1760 s, rice prices began to increase again, reflecting an increase in European demand as continental food production fell behind the rate of population expansion (Nash 1992, p, 692; Dethlof 1982, p. 235). Particularly important in this period was the lifting of prohibitive British tariffs on rice in after 1767, which opened the large British market for the first time. Responding to rising prices, exports shot upward in the decade and a half before the Revolution. As rice production expanded cultivation spread out into Georgia — facilitated by colonists there lifting their prohibition on the use of slave labor-and the Cape Fear region of North Carolina. South Carolina remained by far the largest producer, and exports through Charleston continued to dominate total exports, but the growth of other sources of supply is apparent in Figure 1. By the early 1770s, rice exports from Charleston were in the range of 60-70 million pounds per year, well above the peak reached in the 1740 s, and total American exports were in excess of 80 million pounds annually.

The expansion of markets for rice and indigo after 1750 was reflected in the substantial accumulation of wealth among the colony's free population. As the historian Peter Coclanis (1989, pp. 85-90) has noted "nowhere else in British North America or perhaps in the World for that matter did so sizeable a population live so well." ${ }^{8}$ According to Alice Hanson Jones's study of probate records from 1774, average per capita wealth for the free population in the Charleston district was 416 pounds sterling, more than eight times the level of the middle colonies, and over ten times as great as in New England at this time. Slaves constituted more than half of the wealth in South Carolina, but even without counting slaves, average wealth per free individual in

\footnotetext{
${ }^{8}$ See in addition the contemporary commentaries quoted in Menard (1988, p. 256).
} 
South Carolina was still more than four times that of the average free person in the Middle Colonies. $^{9}$

The upward trajectory of rice exports came to an end with the American Revolution. Material losses during the war were substantial due to the sustained conflict in the region. Perhaps the most important effect was the loss of slaves during the war. The conflict interrupted the importation of slaves, and resulted in a significant decline in the existing slave population. The precise causes of the demographic shock remain unclear, though it seems likely that during the chaotic conditions of the war some slaves seized the opportunity to flee or rebel against planter authority, while others were commandeered by British or American troops. Although data are imprecise, historians have estimated that the regional slave population declined by approximately 25,000 during the war(Morgan 1983, p. 111; Gray 1958, p. 596). The impact of these losses is apparent in Table 2, which suggests that over the course of the 1780s imports of nearly 20,000 slaves increased the slave population by only 10,000 . The decline in the number of slaves, combined with other wartime disruptions, forced planters to forego repairs needed to maintain the complex irrigation systems used in rice cultivation resulting in significant capital depreciation (Chaplin 1992, p. 38).

No systematic export statistics are available for the war years, and data for the postRevolutionary period are neither complete nor entirely consistent. Figure 2 traces rice prices and the volume of exports from Charleston and for the entire U.S. from 1782 to 1810 . That exports from Charleston appear to exceed those from the entire country in a few years is most likely a

\footnotetext{
${ }^{9}$ See Coclanis (1989, p. 125) for these calculations. It should be noted, that if one excludes the value of slaves from wealth, and calculates wealth per capita for the entire population (including slaves), the figure for the lower south (35.9 pounds sterling) is essentially identical to that for the Middle Colonies (40.2 pounds sterling) and New England (36.4 pounds sterling). Thus plantation agriculture enabled free individuals to accumulate substantial wealth, but regional disparities in economic prosperity were largely the result of differences in the inequality of distribution, rather than in the productivity of the underlying economies.
} 
reflection of the fact that the two series were assembled from different sources, and in some cases reflect crop years rather than calendar years. The devastation caused by the war is apparent in the very low levels of exports in the immediate post-war period. Exports rose rapidly in the second half of the 1780 s, but even at their peak in 1793 Charleston's exports were well below the level they had attained in the early 1770s. According to Lewis Gray $(1958$, p. 723$)$ the failure of exports to increase after 1795 can be explained by the combined effects of increased cotton production and the growth of domestic demand for rice.

The destruction of agricultural capital that occurred during the Revolution opened the way for the widespread adoption of tidal irrigation. Even though colonial observers had noted that tide-induced changes in river levels could be used to irrigate rice at least as early as the 1730s, the extensive use of tidal irrigation did not begin until the 1780s (Chaplin 1992, p. 42; Gray 1958, pp. 279-80; Clifton 1981, pp. 275-76; Dethloff 1982, p. 238). In comparison to the use of ponds and reservoirs, tidal irrigation offered a number of benefits. It reduced the risks of unintended flooding, provided a more reliable source of water for the crop, reduced the amount of labor required for weeding, and apparently increased yields-per-acre. But these benefits came at the cost of substantial capital investments. Even today it is possible to see the remains of these irrigation systems which had required enormous investments of labor to create. Embankments five feet high, and narrowing from twelve to fifteen feet wide at their base to three feet at their top, had to be constructed to prevent unwanted flooding. The enclosed fields were then subdivided the enclosed fields into sections by smaller banks, and a system of ditches was built to carry water to each of the sections (see Chaplin 1992, p. 36, Gray 1958, p. 726).

Planters who had already sunk large amounts of money in building irrigation systems were understandably reluctant to undertake the new investments required to implement tidal 
cultivation practices. ${ }^{10}$ But as a result of the loss of labor to maintain these fields during the Revolution, planters in the 1780 s confronted the prospect of having the considerable investments in one kind of irrigation system or another. Many opted for tidal irrigation in the 1780s, but where such a system was not feasible many planters continued to use older irrigation methods.

The stagnation of rice exports after the Revolution was only one change in regional economy. At the same time that planters struggled to rebuild the rice industry, population began to move into the interior of the state. Though the free population had begun to expand beyond the boundaries of the lowcountry in the 1750 s, the trend became much more visible after the war. For the most part, the settlement of the backcountry consisted of independent farmers possessing few if any slaves, and producing only small quantities of marketable crops (Hughes 1985; Johnson 1997, pp. 40-60; Klein 1990, pp. 10-27). As late as 1770 , only $6,000(8.7 \%)$ of the colony's 76,000 slaves lived in the backcountry. In contrast, 30,000 (61\%) of the colony's 49,066 free inhabitants resided in this region (Coclanis 1989, p. 75). Over the next 20 years, the backcountry's share of both free and slave population increased. But the growth was especially dramatic in the slave population, which increased by nearly $400 \%$, growing to slightly more than 29,000 by 1790 . By then, the backcountry's share of the state's slave population had increased to $27 \%$. The introduction and rapid expansion of cotton cultivation beginning in the early $1790 \mathrm{~s}$ reinforced this shift. In 1810 , close to $44 \%$ of the state's slaves were living in the backcountry. Thus, while rice planters remained the dominant users of slave laborers into the early nineteenth century, the stage was set for the ascendance of cotton.

\footnotetext{
${ }^{10}$ So long as the variable costs of production were below the total cost of tidal cultivation it was economically rational for planters to continue using the older practices.
} 


\section{Slave Prices}

Table 3 summarizes the derivation of our estimates of slave prices in low country South Carolina from 1722 through 1809. Our series is based on the appraised values of adult male slaves found in samples of probate inventories from the region that have been collected by William George Bentley and Joyce Chaplin. ${ }^{11}$ To facilitate comparison we have converted all of the values to dollars. ${ }^{12}$

The first column of the table shows average prices for each decade estimated from Chaplin's data for the period from 1740 through 1809. The second column reports estimates from Bentley's data extending from 1722 through $1760 .{ }^{13}$ The two series are not entirely consistent in the years that they overlap, but these differences are not inconsistent with the extent of sampling variation present in the underlying data. To combine the series we use a weighted average of the two sets of observations for the 1740s and 1750s, where the weights reflect the relative number of adult males represented in each sample. To obtain prices for the 1720 s and 1730s we extrapolate backward from the 1740s using the index of price changes calculated from Bentley's data for these years. The resulting Combined Series is shown in column 4 of the table.

The evolution of slave prices depicted in Table 3 can be interpreted in terms of the interaction of supply and demand. ${ }^{14}$ To disentangle these forces it is necessary to formally

\footnotetext{
${ }^{11}$ Bentley collected and analyzed all extant probate inventories for South Carolina from 1722 through 1762 . We have been unable to locate a machine-readable version of Bentley's data. However, he reproduced selected data including information on slave values as an appendix to his dissertation (Bentley 1977), and we have drawn a onein-eight sample from this data set for analysis here. Chaplin's data are a ten percent random sample of extent probate inventories for the period 1740-1815, and are described in Chaplin (1993, pp. 367-68). Professor Chaplin has kindly provided us with a machine-readable version of her data set for analysis.

${ }^{12}$ We first converted the pre-Revolutionary figures, which were reported in South Carolina currency, to pounds sterling using the exchange rates reported in McCusker (1978), and then converted these values to dollars by multiplying by 4.44, the value suggested by McCusker (1992, pp. 313-14).

${ }^{13}$ The decision to aggregate the data by decade is imposed in part by the fact that Chaplin's data are classified only by decade. Given the relatively small size of annual samples, however, a more disaggregated approach would introduce a considerable amount of spurious variation in the series.

${ }^{14}$ Ryden (1993) also used a supply and demand framework to analyze the market for slaves, but in the absence of slave price data for South Carolina, he was obliged to assume that the supply of slaves was perfectly elastic so that
} 
model the process of market equilibration. We begin by discussing the major factors affecting demand and supply, and then specify and estimate an econometric model of the market for slaves in low country South Carolina. ${ }^{15}$

Assuming that planters evaluated the purchase of slaves in an economically rational manner they would have wanted to purchase additional slaves as long as the discounted stream of expected net revenue (gross revenues minus maintenance costs) that each slave was expected to generate exceeded the purchase price. Demand for slaves then would depend positively on the marginal value product of labor, negatively on the cost of food and other necessities, negatively on the opportunity cost of money (the interest rate), and negatively on expected mortality (because of its effect on the length of the stream of expected future income). ${ }^{16}$ Although slaves were employed in a wide variety of activities throughout the economy, rice dominated South Carolina's economy from the 1720 s onward. Thus the demand for slaves was inextricably linked to conditions in the market for rice. ${ }^{17}$

The supply of slaves depended upon the combined effects of natural increase (or decrease) in the resident slave population and importation from abroad. Table 2 summarizes the available information on the relative contributions of natural increase and importation in the growth of the slave population. For the pre-Revolutionary period, relatively complete data on the volume of slave imports is available, but for the post-Revolutionary period, historians have been obliged to impute slave imports on the basis of estimates of the likely course of natural

he could in effect treat it as exogenously determined. As we show below, the evidence contradicts the assumption that prices were exogenously determined.

${ }^{15}$ Factors affecting the supply of and demand for slaves in South Carolina are considered at some length in Ryden (1993); Kenneth Morgan (1998), and Richardson (1991).

${ }^{16}$ In addition to producing marketed crops, slaves generally produced much of their own subsistence as well. Consequently the relevant price of this subsistence was the opportunity cost of their foregone labor in producing marketable crops, which would thus also be tied to the state of demand for rice.

${ }^{17}$ Summarizing planters decisions Kenneth Morgan (1998, p. 914) notes that "Planters calculated whether they could afford slaves mainly on the basis of their projected income from sales of staple produce..... Slave markets were 
increase, in combination with data on the slave population at various dates. ${ }^{18}$ It is clear from these data that imports played a significant role in the expansion of the slave population throughout the entire period. During much of the first half of the eighteenth century, deaths outnumbered births in the colony's slave population, and the number of slaves grew only because of the large volume of imports. In the 1740s, the combined effects of prohibitive tariffs and slack demand for rice combined to reduce importation, but the heavy volume of slave purchases resumed after 1750. Not until the 1790s did natural increase begin to contribute substantially to the growth of the slave population. ${ }^{19}$

In the pre-Revolutionary period, there were few barriers to the importation of slaves into South Carolina, except for the period of prohibitive duties imposed in the wake of the Stono rebellion in 1739. In light of the depressed demand conditions that prevailed in the 1740s, it is not clear that these restrictions were a binding constraint. After 1775, the war and subsequent legislative actions impeded the flow of slaves to varying degrees. During the Revolution the conflict effectively blocked the international slave trade. Although colonists briefly resumed their importation of slaves in the immediate post-war period, the South Carolina legislature in 1787 suspended foreign and domestic imports for three years. The next year legislators passed an act allowing slaves to be imported from other states, but extended the ban on foreign imports until 1793. Subsequent laws continued this prohibition on foreign imports and imposed restrictions on the importation of slaves from other states. ${ }^{20}$ While slaves could not be brought

\footnotetext{
therefore inextricably linked with the economic health of the plantation economy..."

${ }^{18}$ See Philip Morgan (1983, Table 3 and 4) for a discussion of the assumptions underlying calculation of the growth of the slave population.

${ }^{19}$ For a more extensive discussion of slave demography in the first half of the eighteenth century see Menard (1995). According to Morgan (1983, p. 90) the rate of natural increase became positive for the first time in the 1750 s.

${ }^{20}$ South Carolina's delegates to the Constitutional convention were instrumental in delaying the federal ban on slave importation until 1808. Brady's (1972) analysis of voting in the state legislature suggests that support for the restriction of imports in the 1790s derived mainly from large slaveholders and low country residents, while the
} 
from other states to be sold in South Carolina, white settlers could bring essentially unlimited numbers of slaves with them. The relatively high volume of imports in this decade (see Table 2) provides one indication that the restrictions were not a binding constraint. Consistent with this interpretation, when the market for slaves tightened early in the nineteenth century, the legislature removed all restraints on trade. Between 1803, when the ban on imports was lifted, and 1808, when the Constitutionally imposed ban on slave imports took effect, nearly 40,000 slaves were imported into Charleston, though slave traders sold a significant number of these to purchasers outside South Carolina (Brady 1972, pp. 608-15).

Although South Carolina received more slaves than any other mainland colony, it still accounted for only a small fraction of the larger Atlantic slave market in during the colonial period. $^{21}$ Conditions in this external market exerted a powerful influence on slave prices. International supply responses were not, however, perfectly elastic, and localized demand shocks could cause significant price divergences for relatively extended periods. Figure 3 compares our slave price estimates for South Carolina with slave prices in the British West Indies, and, for the colonial period to prices in Maryland. In the long-run the various series display a considerable degree of conformity, but over shorter periods they display considerable independence from one another. $^{22}$

\footnotetext{
owners of small numbers of slaves and back country residents generally supported allowing continued importation. As Brady suggests, low country slave holders supported restrictions on slave imports as a means of moderating the sharp decline in slave prices in the 1790s. But, anticipating the return of more favorable conditions, they wished to keep open the option of further importation in the future.

${ }^{21}$ Richardson (1991, pp. 127-29) estimates that South Carolina imported perhaps 93,000 slaves from 1706 through 1775 , while total slave shipments in this period amounted to about 1.7 million.

${ }^{22}$ Reflecting the long run conformity of the two series, between 1722 and 1809, the correlation coefficient between the South Carolina and British West Indian price series was positive and relatively high (0.72). But the correlation coefficient between the decade to decade changes in prices in the two locations, a measure of the consistency of short-run price movements across locations was -0.46 , indicating that prices tended to move in opposite directions in most decades.
} 
It is apparent that during the early period of the colony's growth—-from the 1720 s until 1740 - slave prices were substantially above the general Atlantic level. The collapse of the market for rice in the 1740s precipitated a pronounced equalization of prices, which then persisted through the 1760s. By the early 1770s, however, prices in South Carolina had again risen well above those in other regions of the New World. The gap in prices between South Carolina and the British West Indies continued to widen in the 1780s. In the 1790s the collapse of slave prices in South Carolina erased this differential and left prices in the region below those in the British West Indies, but after 1800 prices in the South Carolina once again rose above the Atlantic price

These observations allow us to provide an informal account of the evolution of slave prices. The rapid expansion of rice cultivation after 1720 created a substantial demand for slave labor that drove prices well above the prevailing levels in the larger Atlantic economy and initiated a large volume of slave imports. Despite this importation, continued growth in demand for rice kept prices above those in other parts of the Americas throughout the 1720s and 1730s. Only after the collapse of the market for rice in the 1740s was there significant progress toward price equalization. In the 1740 s, slack demand combined with prohibitive tariffs reduced importation. With the recovery of the rice market in the 1750 s and 1760 s prices began to rise gradually initiating renewed importation. The acceleration of growth in the late 1760 s and early 1770s was reflected in the rapid acceleration of slave price increases and very heavy importation in the years immediately preceding the Revolution. The Revolution cut off access to external sources of supply and caused significant reductions in the slave population, thereby contributing to a sharp upward movement in slave prices in the 1780s. Prices fell, however, in the 1790s, reflecting the relatively weak demand for rice at this time. Stronger demand for rice combined 
with the expansion of cotton production after the turn of the century then contributed to a further upward movement in prices after 1800 .

This account can be formalized in a simple econometric model of supply and demand. We assume that the short run supply of slaves $\left(Q^{\mathrm{s}}\right)$ was an increasing function of slave prices in South Carolina (PS), and a decreasing function of their price elsewhere in the Atlantic World, which we proxy by the price of slaves in the British West Indies (PSWI). To capture the effects of supply disruptions caused by the American Revolution we include an indicator variable (WAR) which takes the value one in the 1770 s and 1780 s, and is zero at other times. ${ }^{23}$ In the long-run, the supply curve was substantially more elastic. To reflect the outward shift in supply due to importation and natural increase of the slave population we include a linearly-increasing trend term. Formally, we can write the supply function at time $t$ as:

$$
\mathrm{Q}_{\mathrm{t}}^{\mathrm{s}}=\mathrm{a}_{1}+\mathrm{a}_{2} \mathrm{PS}_{\mathrm{t}}+\mathrm{a}_{3} \operatorname{TREND}_{\mathrm{t}}+\mathrm{a}_{4} \mathrm{WAR}_{\mathrm{t}}+\mathrm{a}_{5} \mathrm{PSWI}_{\mathrm{t}}+\mathrm{e}_{\mathrm{t}}
$$

where $\mathrm{e}$ is a random error term incorporating the net effects of other unmeasured variables.

We model the demand for slaves $\left(\mathrm{Q}^{\mathrm{d}}\right)$ as a declining function of slave prices and an increasing function of the price of rice (PR). Over time the demand for slaves grew for a variety of reasons. Most importantly, the growth of the white population added to the number of potential slave-holders and hence to demand. Increases in slave's life-expectancy and growth in productivity over time may also have contributed to rising demand. To control for these effects we include a linear trend. The demand function at date $t$ can be written as:

$$
\mathrm{Q}_{\mathrm{t}}{ }^{\mathrm{d}}=\mathrm{b}_{1}+\mathrm{b}_{2} \mathrm{PS}_{\mathrm{t}}+\mathrm{b}_{3} \mathrm{PR}_{\mathrm{t}}+\mathrm{b}_{4} \mathrm{TREND}_{\mathrm{t}}+\mathrm{u}_{\mathrm{t}}
$$

where $u$ is a random error reflecting the effects of other unmeasured variables. ${ }^{24}$

\footnotetext{
${ }^{23}$ We experimented with treating the $1740 \mathrm{~s}$ as another period of war induced scarcity, but including the $1740 \mathrm{~s}$ weakens the effect of the WAR variable without substantially affecting any of the other parameter estimates.

${ }^{24}$ A priori it is possible that the WAR variable should also be included as an argument in the demand function. When it is included, however, it's coefficient is not statistically significant and it has little impact on the other
} 
The model is closed by requiring that the price of slaves at each date equilibrates supply and demand. That gives us the following condition:

(3) $\quad Q_{t}{ }^{d}=Q_{t}{ }^{s}$

Because the price of slaves is determined simultaneously with the equilibrium quantity of slaves we cannot treat it as an exogenous variable in estimating the supply and demand functions. Instead we estimate equations (1) and (2) using Instrumental Variables. Our instruments are the four exogenous variables in the model (PR, WAR, TREND, and PSWI).

Table 4 reports our estimates of the supply and demand functions along with reduced form estimates showing the impact of the exogenous variables on each of the two endogenous variables. The coefficients on slave prices in the demand and supply functions have the expected signs, although only the supply function coefficient is statistically significant. Evaluated at the sample means, both supply and demand are less than unit elastic; the supply elasticity is 0.42 , while the demand elasticity is -0.56 . Thus it appears that both short-run supply and demand were relatively inelastic, and we cannot reject the hypothesis that the short-run demand curve was vertical. The coefficients on the trend variable show that supply was growing at a rate of about 9,587 slaves each decade, while the demand was increasing by 12,100 slaves per decade. Thus, the long-run supply response appears to have been slightly outpaced by the growth of demand. This imbalance resulted in a small upward pressure on prices, as reflected by the positive (though insignificant) coefficient on TREND in the reduced form price equation. The large and negative coefficient on the WAR variable indicates that after controlling for other factors, the Revolution substantially reduced the supply of slaves. In the supply equation the price of slaves in the British West Indies enters with the "wrong" sign, though it is statistically insignificant, 
consistent with our earlier argument that in the short-run slave supply and demand conditions dominated the South Carolina market.

The reduced form equations show that the primary determinant of slave prices was the price of rice. At the sample means, the elasticity of slave prices with respect to the price of rice was 1.09 , indicating that a one percent increase in rice prices would cause an increase of 1.09 percent in slave prices. The dummy variable for the Revolutionary war decades is also significant at the thirteen percent level, confirming the role of war-induced scarcity in driving up slave prices. In the quantity equation, the price of rice and the trend variable are positive and marginally statistically significant, while the dummy variable for the Revolutionary War decades is negative, though not very precisely estimated.

\section{Slave Prices, Productivity, and Wealth Accumulation in South Carolina}

Our estimates of slave prices bear directly on several important issues in the economic history of South Carolina, including the pace of productivity advance in rice production and the reasons for the rapid accumulation of wealth in the colony. Over the course of the eighteenth century methods of rice cultivation underwent a series of changes, moving from dry land to irrigated swamps in the 1720 s, and then shifting later in the century to tidal irrigation. Tidal irrigation itself was refined as planters shifted from "flow culture," in which fields were flooded and drained several times, to "water culture," in which fields were kept flooded and the water level raised to keep up with the rice as it grew taller (Chaplin 1992, pp. 32-49). A number of observations from contemporary observers indicate a rise in yields-per-acre, from around 1,000 pounds early in the century to about 1,500 pounds by the time of the Revolution, and an increase 
in output-per-worker from around 2,250 pounds at mid-century to between 3,000 and 3,600 pounds toward the end of the century. ${ }^{25}$

Taken together the evidence of advances in irrigation techniques and the rise in yieldsper-acre and output-per-worker have led to the widely held belief that, as Peter Coclanis (1989, p. 96) put it, "technical improvements in rice cultivation were important sources of aggregate productivity gains." If the latter term were intended to mean total factor productivity, then this conclusion may be overdrawn. There is a difference between increases in partial factor productivity measures such as yields-per-acre and output-per-worker, on the one hand, and advances in total factor productivity, on the other, since partial factor productivity may grow as the result of factor substitution as well as increased productive efficiency. It is apparent from the descriptions of advances in irrigation practices that each advance was associated with an increase in the capital intensity of production. Tidal irrigation, for example, required more extensive investments in dikes, ditches, and the leveling of fields, than earlier methods of irrigation relying on ponds and reservoirs; and those earlier methods were, in turn, substantially more capital intensive than the dry land cultivation practices they replaced. Thus, at least some of the growth in yields-per-acre or output-per-hand must reflect factor substitution rather than advances in productivity.

Our slave price estimates suggest that advances in total factor productivity must have been relatively modest. Intuitively, if total factor productivity rises so that more output can be produced from a fixed set of inputs, then, holding output prices constant, there will be more revenue. This revenue must be paid to one of the factors of production, and will be reflected in a

\footnotetext{
${ }^{25}$ Coclanis (1989, p. 96). These estimates have been widely accepted by other authors. See for example, Philip Morgan (1998, p. 39); Egnal (1998, p. 106); Nash (1992).
} 
rise in the payments to one or more of the inputs to the production process. More formally, begin with the identity between revenues and factor payments:

$$
\mathrm{PQ}=\mathrm{RK}+\mathrm{PL}+\mathrm{WN}
$$

where $\mathrm{P}$ is product price, $\mathrm{Q}$ is output, $\mathrm{K}, \mathrm{L}$ and $\mathrm{N}$ are capital, land and labor, respectively, and $\mathrm{R}$, $\mathrm{P}$, and $\mathrm{W}$ are the payments to the respective factors of production. In the case of slaves, the payments W net of subsistence costs will accrue to the slave's owner. Since slave prices are simply the capitalized value of current and expected future net income, movements in W should produce parallel shifts in slave prices. Dividing through by $\mathrm{P}$, and using lower case variables to denote the real input prices we obtain:

$$
\mathrm{Q}=\mathrm{rK}+\mathrm{pL}+\mathrm{wN}
$$

Differentiating both sides of this expression with respect to time and dividing by Q, yields the following expression:

$$
\mathrm{Q}^{*}=\mathrm{s}_{\mathrm{k}}\left(\mathrm{r}^{*}+\mathrm{K}^{*}\right)+\mathrm{s}_{\mathrm{l}}\left(\mathrm{p}^{*}+\mathrm{L}^{*}\right)+\mathrm{s}_{\mathrm{n}}\left(\mathrm{w}^{*}+\mathrm{N}^{*}\right)
$$

where $\mathrm{s}_{\mathrm{k}}=\mathrm{rK} / \mathrm{Q}, \mathrm{s}_{1}=\mathrm{pL} / \mathrm{Q}$, and $\mathrm{s}_{\mathrm{n}}=\mathrm{wN} / \mathrm{Q}$, are the factor income shares, and an asterisk after a variable denotes its time derivative. Rearranging terms, equation (6) can be written as:

$$
\mathrm{Q}^{*}-\mathrm{s}_{\mathrm{k}} \mathrm{K}^{*}-\mathrm{s}_{\mathrm{l}} \mathrm{L}^{*}-\mathrm{s}_{\mathrm{n}} \mathrm{N}^{*}=\mathrm{s}_{\mathrm{k}} \mathrm{r}^{*}+\mathrm{s}_{\mathrm{l}} \mathrm{L}^{*}+\mathrm{s}_{\mathrm{n}} \mathrm{N}^{*}
$$

The left hand side of this equation, however, is the conventional measure of total factor productivity — the difference between the rate of growth of output and the weighted sum of the growth rates of the inputs. If total factor productivity is increasing, then equation (7) makes clear that this result must show up in an increase in one or more of the real input prices.

In Table 5, we compare the movement of slave prices with those of rice prices from 1722 through 1809. Across the colonial period, from the 1720s through the 1760s, when yields-peracre rose by 50 percent, there is, if anything, a slight downward trend in the real price of slaves. 
The ratio of slave prices to rice prices fell 16 percent from the 1720 s to the 1760 s, before bouncing back in the 1770s. Similarly, across the post-colonial period, the ratio of slave to rice prices remained roughly constant or fell slightly between the 1780 s and the early $1800 \mathrm{~s}$.

The stability of real slave prices does not rule out the possibility of improvements in total factor productivity in rice growing, but it makes it unlikely that such increases could be large enough to explain more than a fraction of the increases in yields-per-acre and output-per worker that occurred over the course of the eighteenth century. Assuming that labor's share of output was 60 percent, the stability of real slave prices implies that the combined payments to land and capital would need to have increased by 150 percent relative to the price of rice, if the 50 percent rise in yields-per-acre in the pre-Revolutionary period was truly a rise in total factor productivity. ${ }^{26}$ Similarly, if the post-Revolutionary increase in output-per-slave of somewhere between 33 and 60 percent was due primarily to total factor productivity growth then the combined prices of land and capital would had to have risen by between 82.5 and 150 percent relative to the price of rice. ${ }^{27}$ The evidence on returns to capital and land is far from complete, but based on the available data increases of this magnitude seem implausible.

The bulk of agricultural capital was in the form of dams, ditches, and other improvements related to irrigation. The primary input in the production of these improvements was slave labor, suggesting that the prices of capital would most likely have moved with the price of slaves. Increases in the price of land may have been more likely, but only if land suitable for the

\footnotetext{
${ }^{26}$ Taking the decline in real slave prices to be $16 \%$ over the pre-Revolutionary period, then if total factor productivity were to have increased by 50 percent, it would be necessary for the weighted average of land and capital prices to rise by a factor of $\left(.5+.16^{*} .6\right) / .4=1.5$. We do not have any direct evidence about factor income shares in the eighteenth century, but for the mid-nineteenth century Coclanis and Komlos (1987) assume that factor shares in rice production were labor- 0.58 , land- 0.25 , and capital-0.17. If anything, we would expect that labor's share of output was larger in the eighteenth century. To the extent that we have understated labor's share our estimates of the increase in land and capital costs needed to account for any given amount of productivity advance will be biased downward.

${ }^{27}$ Recall that output per worker is estimated to have increased from around 2,250 pounds to between 3,000 and
} 
cultivation of rice was in limited supply. The evidence suggests, however, that land remained relatively abundant at least in the colonial period. As production expanded after 1750 planters were able to extend cultivation into previously unexploited lands in Georgia and the Cape Fear region of North Carolina. Further, Loyalist compensation claims suggest that many South Carolina planters held large reserves of unimproved rice land at the time of the Revolution, which suggests that the principal obstacle to expansion was the ability to obtain enough labor to develop and cultivate this land (Nash 1992, p. 693).

In the post-Revolutionary period there is some evidence that the shift to tidal irrigation may have been linked to gains in total factor productivity. Land suitable for tidal irrigation was in relatively scarce supply and prices for this land rose substantially after the Revolution. According to Chaplin (1992, p. 43), at the close of the eighteenth century swamps suited for tidal irrigation sold for about twice the price of inland swamps irrigated from ponds or reservoirs. On the assumption that land's share of output was 25 percent, this doubling in value implies that the move to tidal swamps increased total factor productivity by perhaps 25 percent. Since, only a fraction of rice was grown in tidal swamps, however, the impact of this shift in cultivation on aggregate productivity measures is likely to have been more muted. Thus we can view a 25 percent increase as an extreme upper bound on the potential productivity improvements in rice growing.

Data on deeds of sale from the area surrounding Charleston analyzed by Lee Soltow (1989) suggest that the improvement in productivity was considerably smaller than 25 percent. To establish representative market values of farm land, Soltow edited all published deeds from the region, eliminating entries of less than three acres and those having implausibly low prices. Table 6 reproduces his estimates of land values from 1720 to 1798, and compares them with data 
on the movement of rice prices. Nominal land prices did rise over the course of the century, increasing by perhaps one fifth from the early 1720 s to the early 1770 s, and then growing more rapidly over the next two decades. Deflating by the price of rice, however, produces a rather different pattern. In the colonial period, real land prices appear-if anything — to have fallen slightly. This decline is consistent with evidence that the supply of land was relatively elastic, and implies that there was little or no increase in total factor productivity in the preRevolutionary period. $^{28}$

Soltow's observations for 1794 and 1798, suggest that real land prices did rise after the Revolution, but only by between 24 and 58 percent. This implies a productivity improvement of between 6 and 15 percent stemming from changes in irrigation techniques after the 1770s. This is about one-quarter to one-half the increase implied by the cross-sectional comparison in land prices noted above, and seems consistent with the fact that tidal irrigation techniques affected only a fraction of total production. Even if one accepts the upper limit of this range, it suggests that total factor productivity increases can account for between one quarter and one half of the increase in output per worker after the Revolution, leaving the rest to be interpreted as a consequence of increased land or capital intensity. ${ }^{29}$

Turning to the issue of wealth accumulation, the rise in slave values documented in Table 3 implies that a large part of the wealth found in the low country at the time of the American Revolution was due to rising asset prices, rather than the accumulation of real assets. According

\footnotetext{
${ }^{28}$ The apparent lack of productivity growth in the pre-Revolutionary period implied by factor price movements is consistent with evidence on the volume of rice exports per capita and per slave for this period. Coclanis (1989, $\mathrm{p}$. 82) for example calculates that during the initial expansion of rice cultivation the ratio of aggregate annual rice exports divided by the total slave population increased from 306 pounds per slave in $1708-13$, to 845 pounds per slave by 1728-32, but then leveled off, increasing only to 882.3 pounds per year by 1768-72. Nash (1992) does show that while rice exports were stable, the combined value of rice, indigo, and other crops exported did rise after 1740 , suggesting that the main avenue for productivity growth in agriculture was through diversification that allowed slave labor to be employed more completely throughout the year.

${ }^{29}$ The lower end of this range would apply if output per-slave increased by 60 percent, while the upper end of this
} 
to Bentley (1977) already in the 1720s slaves accounted for 45 percent of estate values, and by the 1750 s this figure had risen to perhaps 51 percent. Calculations based on the sample of probate inventories collected by Joyce Chaplin for the years 1740 to 1809 suggest that slaves made up an even higher proportion of wealth, accounting for about 70 percent of probated wealth in most decades. Average slave holdings per estate were rising in the first half of the centuryincreasing from 7.7 in the 1720 s to 13.3 in the $1730 \mathrm{~s}$, and 19.2 in the $1740 \mathrm{~s}$ - but thereafter they appear to have leveled-off or even fallen slightly. ${ }^{30}$

To examine the impact of changes in slave prices on probate wealth we have constructed counterfactual wealth estimates in which we held the price of slaves constant and compared them with the actual probate wealth series. The results of this comparison are reported in Table 7. The top half of the table compares actual and counterfactual wealth estimates based on Bentley's sample of probate inventories for the period 1722-62, while the bottom half of the table makes the same comparison using Chaplin's sample of probates for the low country from 1740 through 1809. According to the Bentley series, both actual and counterfactual wealth figures increased substantially between the 1720 s and the late 1750 s, with the increase in actual wealth being only about 19 percent greater than the increase calculated by holding slave values constant. Much of the increase in wealth in these years reflected rising slave holdings. ${ }^{31}$ After the 1760 s the actual and counterfactual series diverge more significantly. Actual wealth more than doubled between the 1760 s and 1770 s and grew another 20 percent from the 1770 s to the 1780 s. The

\footnotetext{
range would apply if the increase in output per slave was 33 percent.

${ }^{30}$ Figures for the $1720 \mathrm{~s}, 1730 \mathrm{~s}$, and $1740 \mathrm{~s}$ mentioned in the text were calculated from the one-in-eight sample of Bentley's inventories that we have analyzed. In Chaplin's sample of probate inventories the average number of slaves per inventory fluctuated without apparent trend in the range of 13 to 17 slaves from the 1740 s through the first decade of the nineteenth century. These averages are calculated across all inventories included in the samples, so this overall stability could be consistent with an increasing concentration of slaveholding on larger plantations.

${ }^{31}$ The Chaplin data show a different picture for the $1740 \mathrm{~s}$ and $1750 \mathrm{~s}$, with the average probate wealth level declining. Nevertheless, the difference between the actual and counterfactual figures for the 1750 s using her data was also 19 percent.
} 
counterfactual series increased only 40 percent between the 1760s and 1770s, and hardly at all over the next decade. Over the entire 70 years covered by Chaplin's data actual wealth nearly doubled, while our counterfactual series was actually lower in the early nineteenth century then it had been in the 1740 s.

These results do not of course controvert earlier findings that have emphasized the rising prosperity of colonial South Carolina, but they place these findings in a rather different light. Rather than reflecting the accumulation of real assets, the region's rising wealth after 1740 was the consequence mostly of increases in asset prices driven by world demand for the region's primary staple commodities.

\section{Conclusion}

We have used data available in samples of probate inventories from South Carolina to construct a long-term series of slave prices covering the period from 1722 to 1809 . These estimates reveal that slave prices fell moderately between the 1720 s and 1740 s, before beginning to rise. The rate of price increases accelerated after 1770, and despite a sharp drop in the 1790s, prices had more than doubled by the early nineteenth century. Although the long-run supply of slaves was probably close to perfectly elastic, the short-run supply curve was relatively inelastic. In these circumstances, the growth of world markets for rice contributed to rising output prices which, in turn, helped to push up slave prices after the middle of the eighteenth century.

These findings have several important implications for our understanding of the economic history of South Carolina. First, they suggest that a significant fraction of the rise in yields-per-acre and output-per-slave that occurred in rice cultivation across the eighteenth century was the product of increased application of capital in the form of more expensive 
irrigation systems, rather than an improvement in total factor productivity. Total factor productivity did increase, but the combined evidence from factor prices implies that these advances can account for only a fraction of the change in yields-per-acre and output-per slave that are believed to have taken place. The evidence on land and capital prices is far from complete, however, and further research into their behavior would seem desirable. Second, the long-run rise in slave prices appears to have been responsible for much of the increase in the region's prosperity in this period. This finding suggests that rather than accumulating more physical assets, slaveholders were becoming wealthy through capital gains realized because of strong demand for the region's primary product, which drove up the value of labor. As long as the short-run supply of slaves remained relatively inelastic, the owners of this scarce resource were able to capture significant scarcity rents in the form of rising slave prices. 


\section{References}

Bean, Richard Nelson. 1975. The British Trans-Atlantic Slave Trade, 1650-1775. New York: Arno Press.

Bentley, William George. 1977. "Wealth Distribution in Colonial South Carolina." Ph. D. diss. Georgia State University.

Brady, Patrick S. 1972. "The Slave Trade and Sectionalism in South Carolina, 1787-1808." Journal of Southern History 38, no. 4 (Nov.), 601-20.

Chaplin, Joyce E. 1992. "Tidal Rice Cultivation and the Problem of Slavery in South Carolina and Georgia, 1760-1815." William and Mary Quarterly $3^{\text {rd }}$. Ser., 49, no. 1 (Jan.), 29-61.

Chaplin, Joyce E. 1993. An Anxious Pursuit: Agricultural Innovation and Modernity in the Lower South, 1730-1815. Chapel Hill and London: University of North Carolina Press for the Institute of Early American History and Culture, Williamsburg, VA.

Clifton, James M. 1981. "The Rice Industry in Colonial America.” Agricultural History 55, no. 3 (July), 266-83.

Coclanis, Peter A. 1989. The Shadow of a Dream: Economic Life and Death in the South Carolina Low Country, 1670-1920. New York and Oxford: Oxford University Press.

Coclanis, Peter and John Komlos. 1987. "Time in the Paddies: A Comparison of rice Production in the Southeastern United States and Lower Burma in the Nineteenth Century.” Social Science History 11, no. 3 (Fall), 343-54.

Cole, Arthur Harrison. 1938. Wholesale Commodity Prices in the United States, 1700-1861. Cambridge, MA: Harvard University Press.

Coon, David Leroy. 1972. “The Development of Market Agriculture in South Carolina, 16701785." Ph. D. Diss., University of Illinois. 
Crouse, Maurice A. 1977. The Public Treasury of Colonial South Carolina. Columbia, SC: University of South Carolina Press for the South Carolina Tricentennial Commission.

Dethloff, Henry C. 1982. “The Colonial Rice Trade.” Agricultural History 56, no. 1 (Jan.), 23143.

Duncan, John Donald. 1971. "Servitude and Slavery in Colonial South Carolina, 1670-1776." Ph. D. diss. Emery University.

Egnal, Marc. 1998. New World Economies: The Growth of the Thirteen Colonies and Early Canada. New York and Oxford: Oxford University Press.

Gray, Lewis Cecil. 1958. History of Agriculture in the Southern United States to 1860. 2 volumes. Gloucester, MA: Peter Smith.

Hsieh, Chang-Tai. 1999. "Productivity Growth and Factor Prices in East Asia." American Economic Review 89, no. 2 (May), pp. 133-38.

Hughes, Kaylene. 1985. "Populating the Back Country: The Demographic and Social Characteristics of the Colonial South Carolina Frontier, 1730-1760.” Ph. D. Diss., Florida State University.

Johnson, George Lloyd, Jr. 1997. The Frontier in the Colonial South: South Carolina Backcountry, 1736-1800. Contributions in American History, no. 175. Westport, CT and London: Greenwood Press.

Klein, Rachel N. 1990. Unification of a Slave State: The Rise of the Planter class in the South Carolina Backcountry, 1760-1808. Chapel Hill, NC and London: University of North Carolina Press for the Institute of Early American History and Culture.

Kulikoff, Alan. 1976. “Tobacco and Slaves: Population, Economy and Society in Eighteenth Century Prince George’s County, Maryland.” Ph.D. diss, Brandeis University. 
LeVeen, E. Phillip. 1977. British Slave Trade Suppression Policies, 1821-1865. New York: Arno Press.

Mancall, Peter C., Joshua L. Rosenbloom, and Thomas Weiss. 1999. "Indians and the Economy of Eighteenth-Century Carolina." Paper presented at the Emergence of the Atlantic Economy Conference. Charleston, SC, October 1999.

Mancall, Peter C., Joshua L. Rosenbloom, and Thomas Weiss. 2000. "Slave Prices in the Lower South, 1722-1815.” NBER Historical Working Paper no. 120 (January 2000).

McCusker, John J. (1992). How Much is That in Real Money? A Historical Price Index for Use as a Deflator of Money Values in the Economy of the United States. Worcester, MA: American Antiquarian Society.

McCusker, John J. (1978). Money and Exchange in Europe and America, 1600-1775: A Handbook. Chapel Hill: University of North Carolina Press for the Institute of Early American History and Culture.

Menard, Russell R. 1988. "Slavery, Economic Growth, and Revolutionary Ideology in the South Carolina Lowcountry." In Ronald Hoffman et al, eds. The Economy of Early America: The Revolutionary Period, 1763-1790. Charlottesville: University of Virginia Press. Menard, Russell R. 1995. "Slave Demography in the Lowcountry, 1670-1740: From Frontier Society to Plantation Regime.” South Carolina Historical Magazine 96, no. 4 (Oct.), 280303.

Menard, Russell R., 1996. "Economic and Social Development of the South.” In Stanley L. Engerman and Robert E. Gallman, eds. The Cambridge Economic History of the United States, vol.1: "The Colonial Era." Cambridge: Cambridge University Press. 
Morgan, Kenneth. 1998. "Slave Sales in Colonial Charleston.” English Historical Review 113, no. 453 (Sept.), 905-27.

Morgan, Philip D. 1983. "Black Society in the Lowcountry, 1760-1810," in Ira Berlin and Ronald Hoffman, eds., Slavery and Freedom in the Age of the American Revolution. Charlottesville, VA: University of Virginia Press for the United States Capitol Historical Society.

Morgan, Philip D. 1998. Slave Counterpoint: Black Culture in the Eighteenth-Century Chesapeak and Lowcountry. Chapel Hill and London: University of North Carolina Press for the Omohundro Institute of Early American History and Culture.

Nash, R. C. 1992. "South Carolina and the Atlantic Economy in the Late Seventeenth and Eighteenth Centuries.” Economic History Review 45, no. 4, pp. 677-701.

Richardson, David. 1991. "The British Slave Trade to Colonial South Carolina." Slavery and Abolition 12, no. 3 (Dec.), 125-72.

Ryden, David Beck. 1993. "The Slave Trade of Colonial Charleston: A Formal Analysis of Supply and Demand.” M.A. Thesis, University of Delaware.

Terry, George David. 1981. "'Champagne Country': A Social History of an Eighteenth Century Low Country Parish in South Carolina, St. Johns Berkeley Parish.” Ph. D. diss. University of South Carolina.

United States, Bureau of the Census. 1975. Historical Statistics of the United States, Colonial Times to 1970. Bicentennial Edition. 2 vols. Washington, DC: GPO.

Wood, Peter H. 1974. Black majority; Negroes in Colonial South Carolina from 1670 through the Stono Rebellion. New York: Knopf. 
Table 1:

South Carolina Population, 1700-1809

\begin{tabular}{rrrrr}
\hline \hline & & & \multicolumn{2}{c}{ Slave } \\
\cline { 4 - 5 } Year & \multicolumn{1}{c}{ Total } & \multicolumn{1}{c}{ Free } & Number & Percentage \\
\hline 1700 & 5,704 & 3,260 & 2,444 & 42.85 \\
1710 & 10,883 & 6,783 & 4,100 & 37.67 \\
1720 & 17,048 & 5,048 & 12,000 & 70.39 \\
1730 & 30,000 & 10,000 & 20,000 & 66.67 \\
1740 & 45,000 & 15,000 & 30,000 & 66.67 \\
1750 & 64,000 & 25,000 & 39,000 & 60.94 \\
1760 & 94,074 & 36,740 & 57,334 & 60.95 \\
1770 & 124,244 & 49,066 & 75,178 & 60.51 \\
1780 & 180,000 & 83,000 & 97,000 & 53.89 \\
1790 & 249,073 & 141,979 & 107,094 & 43.00 \\
1800 & 345,591 & 199,440 & 146,151 & 42.29 \\
\hline
\end{tabular}

Notes and Sources: U.S. Census Bureau (1975, series Z15-17, and series A195, A199-200). 
Table 2:

Source of Growth of the

South Carolina Slave Population, 1720-1809

\begin{tabular}{ccccccc}
\hline \hline & \multicolumn{3}{c}{ Slave Population } & & \multicolumn{2}{c}{ Slaves Imported } \\
\cline { 2 - 4 } \cline { 5 - 6 } Period & $\begin{array}{c}\text { Beginning of } \\
\text { Period }\end{array}$ & End of Period & $\begin{array}{c}\text { Change over } \\
\text { preceding } \\
\text { decade }\end{array}$ & & & Ratio of \\
Imports to \\
$1700-1710$ & 2,444 & 4,100 & 1,656 & & 3,000 & 1.81 \\
$1710-1720$ & 4,100 & 12,000 & 7,900 & & 6,000 & 0.76 \\
$1720-1730$ & 12,000 & 20,000 & 8,000 & & 11,600 & 1.45 \\
$1730-1740$ & 20,000 & 30,000 & 10,000 & & 21,150 & 2.12 \\
$1740-1750$ & 30,000 & 39,000 & 9,000 & & 1,950 & 0.22 \\
$1750-1760$ & 39,000 & 57,334 & 18,334 & & 16,497 & 0.90 \\
$1760-1770$ & 57,334 & 75,178 & 17,844 & & 21,840 & 1.22 \\
$1770-1780$ & 75,178 & 97,000 & 21,822 & & 18,866 & 0.86 \\
$1780-1790$ & 97,000 & 107,094 & 10,094 & & 19,200 & 1.90 \\
$1790-1800$ & 107,094 & 146,151 & 39,057 & & 19,991 & 0.51 \\
$1800-1810$ & 146,151 & 196,365 & 50,214 & & 30,195 & 0.60 \\
\hline
\end{tabular}

Notes and Sources: Slave population from U.S. Census Bureau (1975, series Z15-17, and series A195, A199-200); Slave imports from Morgan (1983, p. 87), and Philip Morgan (1998, p. 59). Through 1775, there are reasonably complete data on the number of slaves imported into South Carolina. After 1775, it is necessary to impute the volume of imports using an estimate of the rate of increase of the resident population, and then calculating the difference between actual and estimated population at each date. 
Table 3:

Derivation of the Prices of Adult Male Slaves in Low Country South Carolina, 1722-1809

\begin{tabular}{|c|c|c|c|c|}
\hline \multirow[b]{2}{*}{ Period } & \multirow{2}{*}{$\begin{array}{l}\text { Chaplin } \\
\text { Value (\$) } \\
\text { (1) }\end{array}$} & \multicolumn{2}{|c|}{ Bentley } & \multirow{2}{*}{$\begin{array}{l}\text { Combined } \\
\text { Value (\$) } \\
\text { (4) }\end{array}$} \\
\hline & & $\begin{array}{c}\text { Value (\$) } \\
\text { (2) }\end{array}$ & $\begin{array}{c}\text { Index } \\
(1740-49=100) \\
(3)\end{array}$ & \\
\hline $1722-29$ & & 183.7 & 110.1 & 164.1 \\
\hline 1730-39 & & 196.3 & 117.6 & 175.4 \\
\hline $1740-49$ & 117.9 & 166.9 & & 149.2 \\
\hline $1750-59$ & 160.7 & 179.4 & & 167.7 \\
\hline $1760-69$ & 154.3 & & & 154.3 \\
\hline $1770-79$ & 245.7 & & & 245.7 \\
\hline $1780-89$ & 343.5 & & & 343.5 \\
\hline 1790-99 & 197.2 & & & 197.2 \\
\hline 1800-09 & 393.2 & & & 393.2 \\
\hline $1810-15$ & 343.5 & & & 343.5 \\
\hline
\end{tabular}

Notes and Sources: Column (1) is derived from a machine-readable sample of probate inventories collected by Joyce Chaplin. See Chaplin (1993, pp. 367-68) for details about the data. Because Chaplin reports only an aggregate value for all slaves, we have estimated the value of adult males using a regression framework that controls for the age and sex composition of slaveholdings in each estate. Details of this procedure are described in Mancall, Rosenbloom, and Weiss (2000). Beginning with data for 1780, we also include dummy variables to control for possible regional differences in slave values between the low country and other parts of the state. Chaplin does not provide location information before this date, but the number of estates from outside the low country is not very large in these earlier years. Column (2) is derived from a one-in-eight random sample of probate inventories summarized in Bentley (1977). For 1740-49 and 1750-59 the combined series in Column (4) is a weighted average of the Chaplin and Bentley series, where the weights are the relative number of observations on which each estimate is based. For years before 1740, the series is extrapolated by applying the changes in the Bentley series to the value of the Combined series in 1740-49. 
Table 4:

Estimates of Determinants of Supply of and

Demand for Slaves, 1722-1809

\begin{tabular}{|c|c|c|c|c|c|c|c|c|}
\hline \multirow[b]{3}{*}{ Variable } & \multicolumn{4}{|c|}{ Structural Model } & \multicolumn{4}{|c|}{ Reduced Form Equations } \\
\hline & \multicolumn{2}{|c|}{ Supply } & \multicolumn{2}{|c|}{ Demand } & \multicolumn{2}{|c|}{ Price } & \multicolumn{2}{|c|}{ Quantity } \\
\hline & $\begin{array}{l}\text { Parameter } \\
\text { (s.e) }\end{array}$ & $P>|t|$ & $\begin{array}{c}\text { Parameter } \\
\text { (s.e) }\end{array}$ & $P>|t|$ & $\begin{array}{c}\text { Parameter } \\
\text { (s.e) }\end{array}$ & $P>|t|$ & $\begin{array}{c}\text { Parameter } \\
\text { (s.e) }\end{array}$ & $P>|t|$ \\
\hline PS & $\begin{array}{l}141.4 \\
(46.4)\end{array}$ & 0.04 & $\begin{array}{l}-195.2 \\
(178.7)\end{array}$ & 0.33 & & & & \\
\hline TREND & $\begin{array}{c}9587.4 \\
(4502.2)\end{array}$ & 0.10 & $\begin{array}{l}12099.86 \\
(3564.8)\end{array}$ & 0.02 & $\begin{array}{c}10.30 \\
(21.58)\end{array}$ & 0.48 & $\begin{array}{l}11044.1 \\
(6282.9)\end{array}$ & 0.15 \\
\hline WAR & $\begin{array}{c}-18244.1 \\
(6196.8)\end{array}$ & 0.04 & & & $\begin{array}{c}51.77 \\
(27.62)\end{array}$ & 0.13 & $\begin{array}{r}-10923.9 \\
(8039.5)\end{array}$ & 0.25 \\
\hline PR & & & $\begin{array}{c}38205.0 \\
(21578.3)\end{array}$ & 0.14 & $\begin{array}{l}114.36 \\
(25.80)\end{array}$ & 0.01 & $\begin{array}{l}16170.1 \\
(7508.5)\end{array}$ & 0.10 \\
\hline PSWI & $\begin{array}{c}295.6 \\
(203.3)\end{array}$ & 0.22 & & & $\begin{array}{l}-1.02 \\
(1.02)\end{array}$ & 0.38 & $\begin{array}{c}151.5 \\
(297.6)\end{array}$ & 0.64 \\
\hline Intercept & $\begin{array}{l}-40922.3 \\
(18771.4)\end{array}$ & 0.10 & $\begin{array}{l}-10437.2 \\
(13353.7)\end{array}$ & 0.47 & $\begin{array}{l}101.95 \\
(87.84)\end{array}$ & 0.31 & $\begin{array}{l}-26506.7 \\
(25570.2)\end{array}$ & 0.36 \\
\hline $\begin{array}{l}\text { R- } \\
\text { Squared }\end{array}$ & 0.99 & & 0.96 & & 0.93 & & 0.98 & \\
\hline
\end{tabular}

Notes and Sources: The dependent variable in the structural model, and the reduced form quantity model is the mean of the number of slaves in South Carolina at the beginning and end of each decade. The dependent variable in the reduced form price equation is PS, the average price of adult male slaves in each decade. TREND is a linearly increasing term that begins at zero in the 1720 s and increases by one in each subsequent decade; WAR is a dummy variable equal to one in the 1770s and 1780s, and zero otherwise; PR is the average price of rice in each decade. Figures in parentheses are the standard errors; PS-WI is the decade average price of slaves in the British West Indies. Prices for 1722-1775 from Bean (1975, p. 77). We extrapolate the series beyond 1775 using changes in prices as estimated by LeVeen (1977, pp. 146-47). The column labeled $\mathrm{P}>|\mathrm{t}|$ shows the probability that the estimated parameter is statistically significantly different from zero. 
Table 5:

Decade Average Prices of Slaves and Rice, 1722-1809

\begin{tabular}{|c|c|c|c|}
\hline Period & $\begin{array}{l}\text { Slave Price } \\
\text { (\$/adult male) }\end{array}$ & $\begin{array}{c}\text { Rice Price } \\
\text { (cents/pound) }\end{array}$ & $\begin{array}{c}\text { Index of Slave Price } \\
\text { Relative to the Price } \\
\text { of Rice } \\
(1722-29=100)\end{array}$ \\
\hline $1722-29$ & 164.16 & 1.40 & 100.0 \\
\hline $1730-39$ & 175.43 & 1.64 & 91.4 \\
\hline $1740-49$ & 149.16 & 1.18 & 108.1 \\
\hline $1750-59$ & 167.74 & 1.56 & 92.0 \\
\hline $1760-69$ & 154.30 & 1.58 & 83.8 \\
\hline $1770-79$ & 245.70 & 1.87 & 112.6 \\
\hline $1780-89$ & 343.50 & 3.15 & 93.3 \\
\hline $1790-99$ & 197.20 & 2.73 & 61.8 \\
\hline 1800-09 & 393.20 & 3.81 & 88.4 \\
\hline
\end{tabular}

Notes and Sources: Slave prices from Table 3, rice prices are from Cole $(1938$, p. 152) and Coclanis (1989, p. 107). 
Table 6:

Land Values per Acre and Rice Prices, 1720-1798

\begin{tabular}{lccc}
\hline \hline & $\begin{array}{c}\text { Land Value per Acre } \\
\text { (current \$) }\end{array}$ & $\begin{array}{c}\text { Index of Land Value } \\
\text { Price of Rice } \\
\text { (cents/pount) }\end{array}$ & $\begin{array}{c}\text { Relative to Price of Rice } \\
(1720-24=100)\end{array}$ \\
\hline $1720-24$ & 1.25 & $1.28^{\mathrm{a}}$ & 100.0 \\
$1725-29$ & 1.26 & 1.48 & 87.6 \\
$1730-34$ & 1.16 & 1.42 & 84.1 \\
$1735-39$ & 0.94 & 1.87 & 51.7 \\
$1740-44$ & 1.17 & 1.25 & 96.0 \\
$1745-49$ & 1.45 & 1.11 & 134.5 \\
$1750-54$ & 1.44 & 1.74 & 85.1 \\
$1755-59$ & 2.08 & 1.38 & 154.5 \\
$1760-64$ & 2.05 & 1.35 & 156.1 \\
$1765-69$ & 2.04 & 1.80 & 116.6 \\
$1770-75$ & 1.56 & 1.92 & 83.4 \\
1794 & & & \\
1798 & 3.44 & $2.86^{\mathrm{b}}$ & 123.6 \\
\hline
\end{tabular}

a Average price of rice for the three-year period 1722-24.

b Average price of rice for the five-year period 1794-98.

Notes and Sources: land values are from Soltow (1989, pp. 202-3). Soltow reported land values deflated by the cost of living. To obtain nominal values we have multiplied his figures by the average cost of living index for the corresponding period derived from McCusker (1992, Table A-2). The price of rice is from Cole (1938, p. 152) and Coclanis (1989, p. 107). 
Table 7:

Average Actual and Counterfactual Wealth per Inventoried Decedent, 1722-1809

\begin{tabular}{|c|c|c|c|c|c|}
\hline \multirow[b]{2}{*}{ Period } & \multicolumn{2}{|c|}{ Average Wealth (\$) } & \multicolumn{2}{|r|}{ Index } & \multirow{2}{*}{$\begin{array}{c}\text { Ratio } \\
\text { Actual/ } \\
\text { Counterfactual }\end{array}$} \\
\hline & Actual & Counterfactual & Actual & Counterfactual & \\
\hline \multicolumn{6}{|c|}{ Bentley } \\
\hline & & & \multicolumn{2}{|c|}{$(1722-26=100)$} & \\
\hline $1722-26$ & 1851 & 1906 & 100 & 100 & 100 \\
\hline $1727-31$ & 1696 & 1730 & 92 & 91 & 99 \\
\hline $1732-36$ & 1935 & 1867 & 105 & 98 & 107 \\
\hline $1737-41$ & 1889 & 2178 & 102 & 114 & 89 \\
\hline $1742-46$ & 2575 & 2575 & 139 & 135 & 103 \\
\hline $1747-51$ & 3136 & 2973 & 169 & 156 & 108 \\
\hline $1752-56$ & 3414 & 3215 & 184 & 169 & 109 \\
\hline $1757-62$ & 3830 & 3324 & 207 & 174 & 119 \\
\hline \multicolumn{6}{|c|}{ Chaplin } \\
\hline \multicolumn{6}{|c|}{$(1740-49=100)$} \\
\hline $1740-49$ & 2398 & 2477 & 100 & 100 & 100 \\
\hline $1750-59$ & 1992 & 1730 & 83 & 70 & 119 \\
\hline $1760-69$ & 2653 & 1970 & 111 & 80 & 139 \\
\hline $1770-79$ & 5879 & 2776 & 245 & 112 & 219 \\
\hline $1780-89$ & 6935 & 2808 & 289 & 113 & 256 \\
\hline $1790-99$ & 4370 & 2777 & 182 & 112 & 163 \\
\hline 1800-09 & 4772 & 2358 & 199 & 95 & 209 \\
\hline
\end{tabular}

Notes and Sources: Bentley's probate wealth data are reproduced in Coclanis $(1989$, p. 85). The counterfactual series was calculated by subtracting the share of wealth in each period attributable to slaves and then deflating the slave share of wealth using a price index set equal 100 in 174246. The slave price index was calculated from a one-in-eight random sample of slave values drawn from date reproduced in Bentley (1977). The actual and counterfactual wealth series from Chaplin's sample were calculated from the machine-readable version of her data. After 1780 they are limited to the South Carolina low country estates only. The counterfactual series was calculated by subtracting the total value of slaves from each inventory, and then valuing slaves at the prices prevailing in the $1740 \mathrm{~s}$. Where the age and sex of slaves was enumerated separate price data for each age sex category were used. When information on age and sex were not available, a weighted average of prices of slaves in each age and sex categories was used, where the weights were the shares of different age/sex groups in those estates for which information on age and sex were available. 
Figure 1

Rice Exports (pounds) and Price (cents/pound), 1698-1722

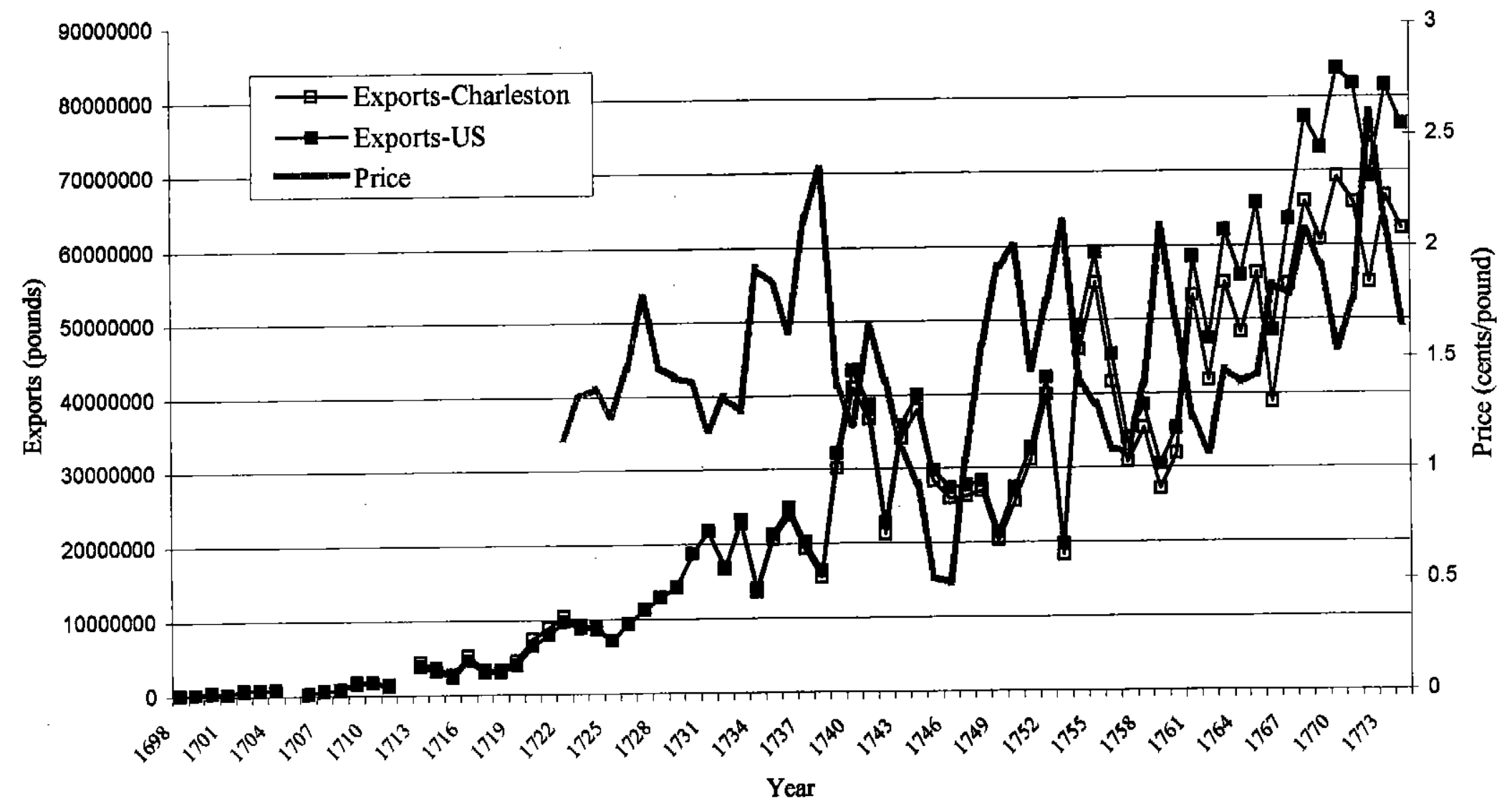

Notes and Sources: Exports-Charleston splices Coon's (1972, pp. 349-50) estimates for 1698-1724 and U.S. Bureau of the Census (1975, Series Z483) for 17251774; Exports-US is total exports for South Carolina and Georgia from U.S. Bureau of the Census (1975, Series Z481); Price data are from Coclanis (1989, p. 107), and Cole (1938, p. 154) 
Figure 2

Rice Exports (pounds) and Price (cents/pound), 1782-1810

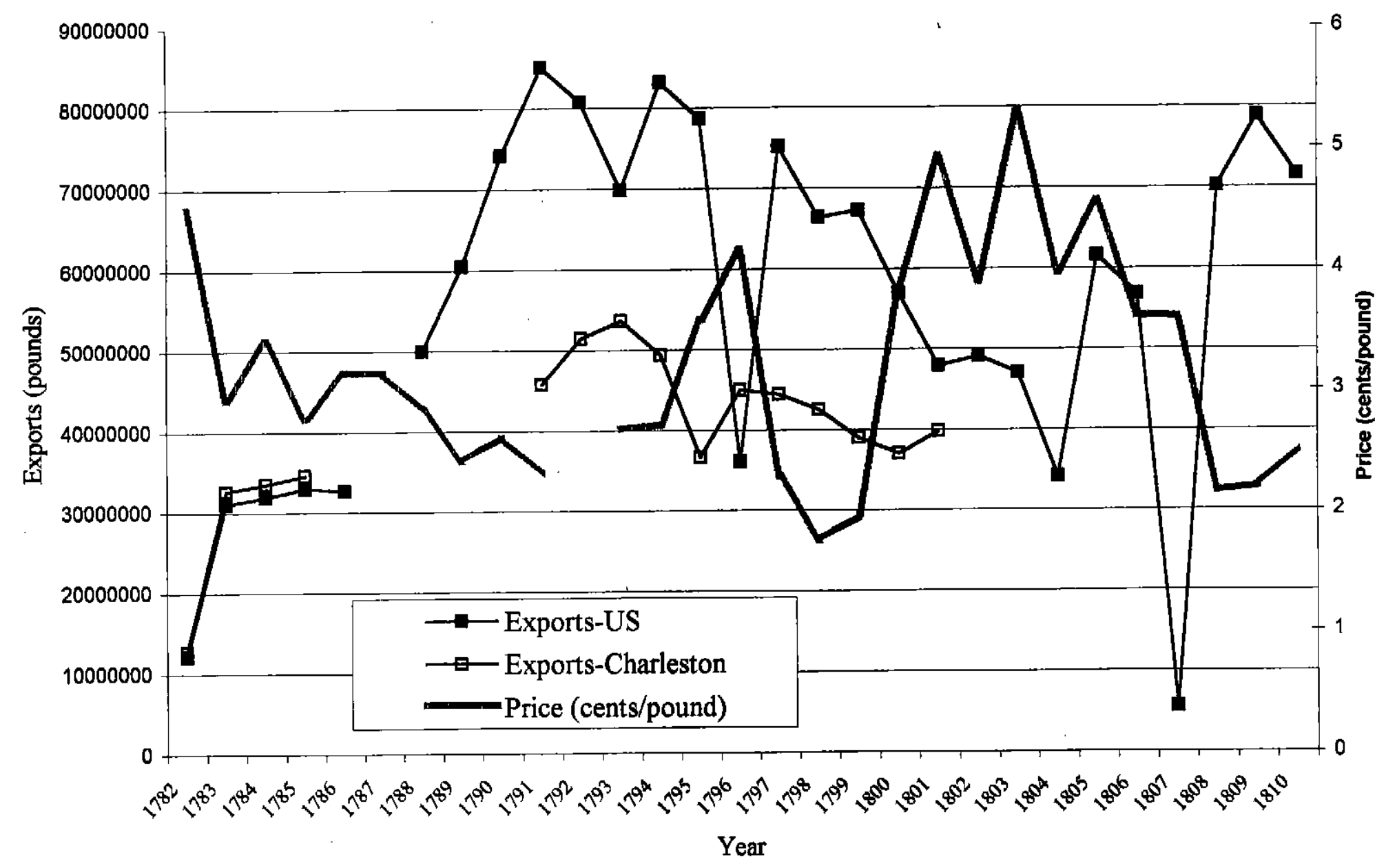

Sources: Exports-US from Gray (1958, p. 1030); Exports-Charleston from Gray (1958, p. 1022); price of rice from Cole (1938, p. 154) 
Figure 3:

Comparison of Slave Prices in South Carolina, Maryland, and British West Indies, 1722-1809

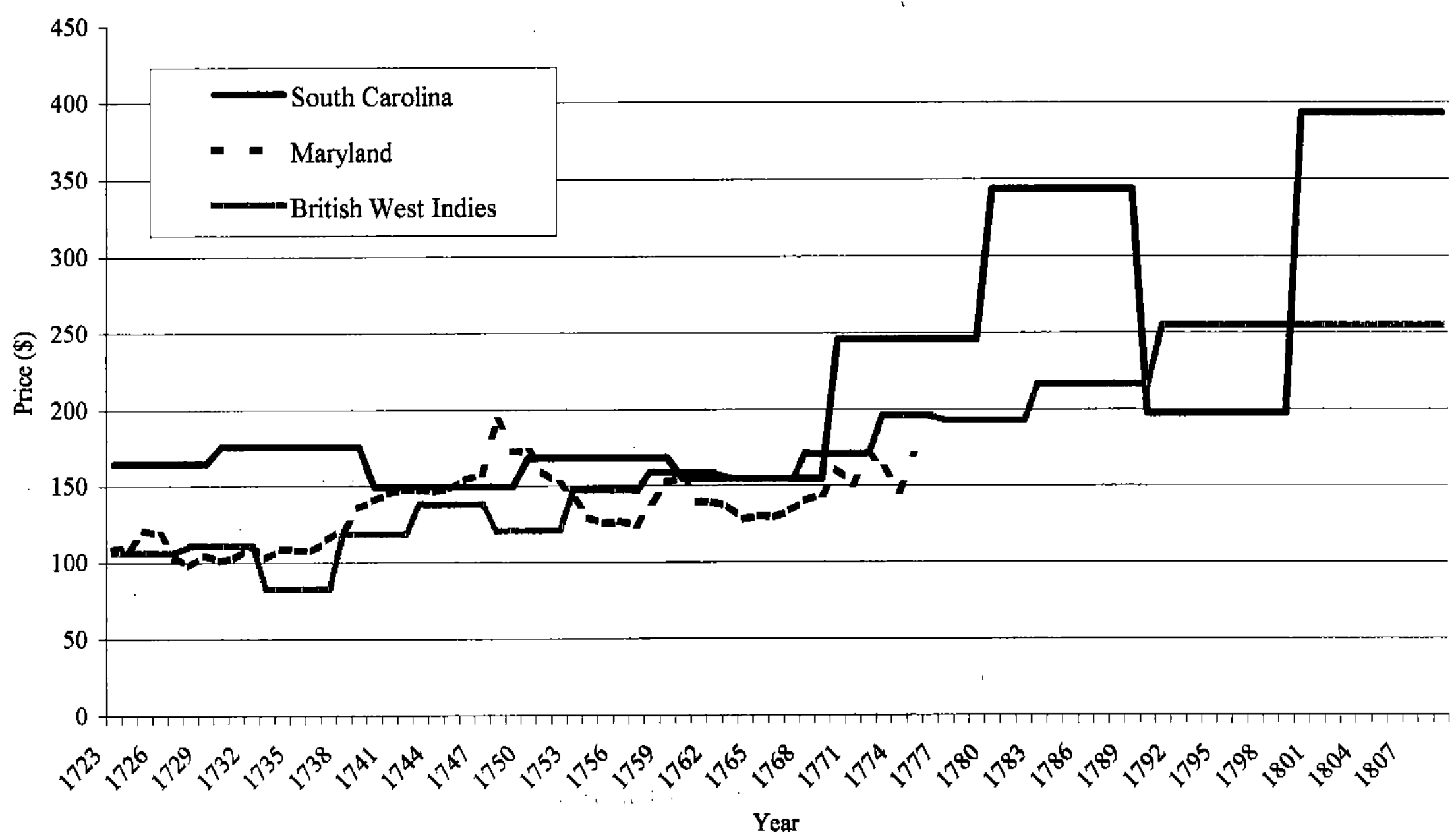

Source; South Carolina from Table 2; Maryland from Kulikoff (1976, pp. 485-88); British West Indles from Bean (1975, p. 77) and LeVeen (1977, pp. 146-47). 